\begin{abstract}
مقاله بزوهشى
مجله دانشخاه علوم يزشكى رفسنجان

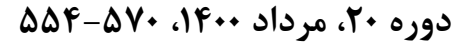

\section{بروسى ارتباط قدردانى و حمايت اجتماعى ادراكى شده با شاد كامى زنان كوويل-9 1: يكى مطالعه توصيفى سكر}

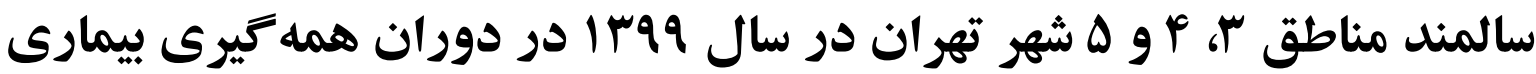

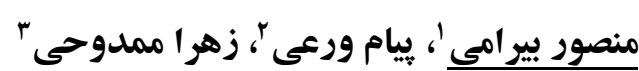

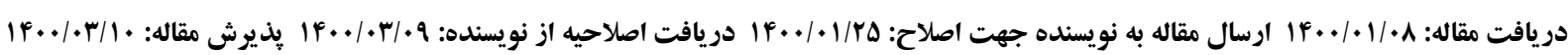

زمينه و هدف: شاد كامى از متغيرهاى روانشناسى مثبتنكر است كه مى تواند بر زندكى سالمندان تأثير كذار باشد. بنابراين مطالعه حاضر

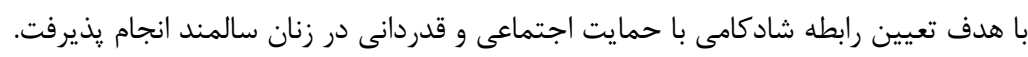

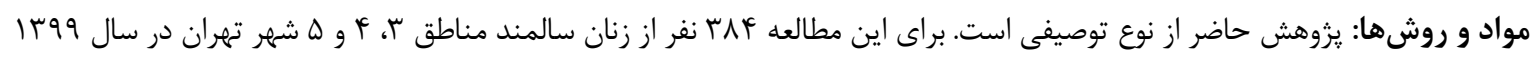

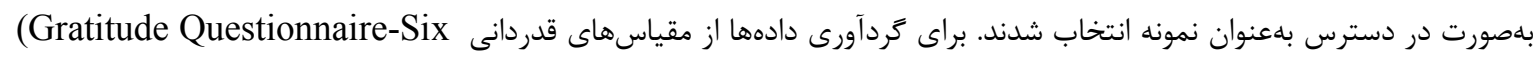

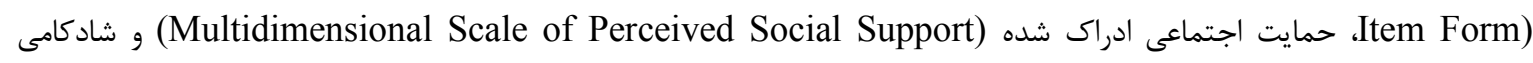

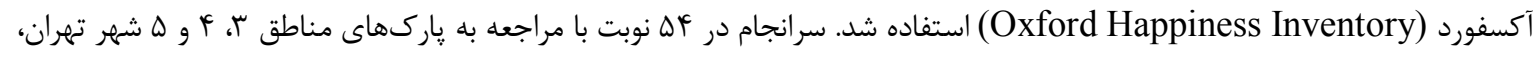

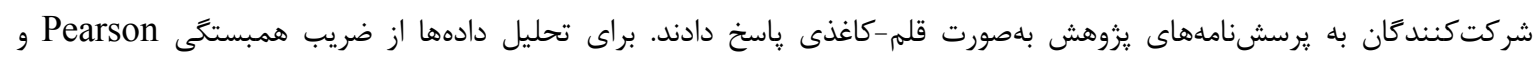
ركرسيون خطى گَامبه گام استفاده شد.

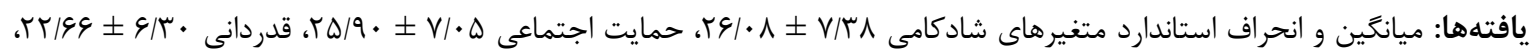

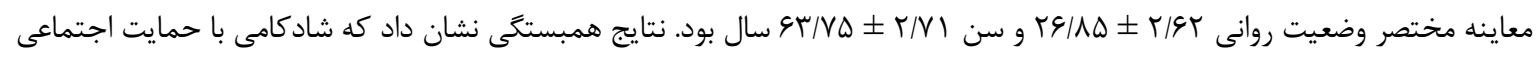

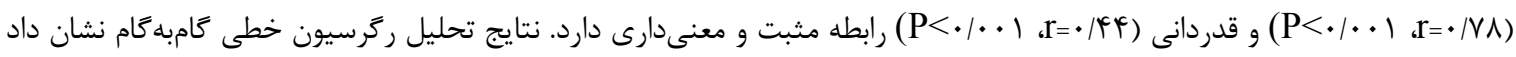

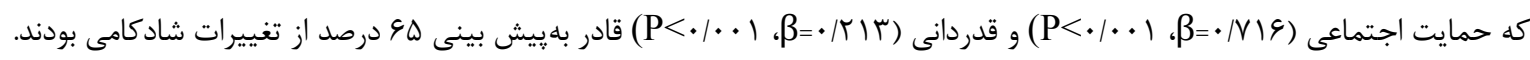

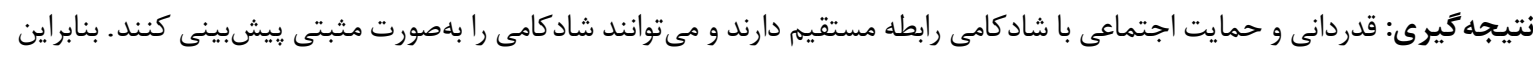

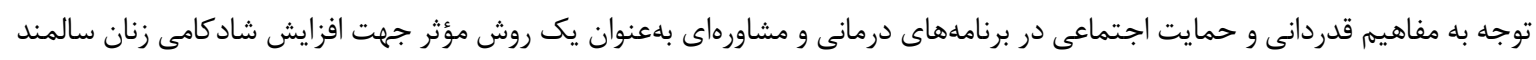
مى تواند مفيد باشد. وازمهاى كليدى: حمايت اجتماعى، زنان سالمند، شادكامى، قدردانى، كرونا ويروس، تهران
\end{abstract}

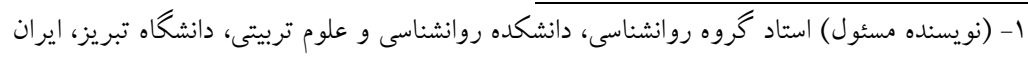

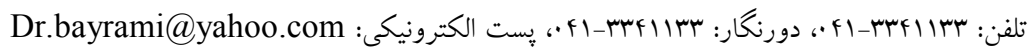

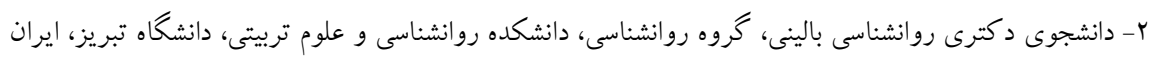

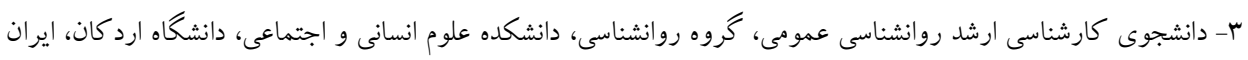


سلامت روان، رضايت از زندكى و سلامت عمومى سالمندان

در ارتباط است. در داخل كشور نيز Keykhosravi Geygzadeh و همكاران [هoudarz و همكاران [ع [1 [1 به اين نتيجه رسيدند كه حمايت اجتماعى در سالمندان مىتواند باعث افزايش شادكامى، ارتقاء ميزان رضايتمندى از زندگى و بهزيستى روانى آنان گردد. اما مطالعات تجربى ديخرى نشان مىدهد كه حمايت اجتماعى مى تواند بهصورت منفى نيز وجود داشته باشد به اين صورت كه دريافت حمايت از جانب ديگران ممكن است عاطفه منفى مثل حس فرسودهشن، وابستخى و غمخينى را نيز به همراه داشته باشد و درنتيجه اين حمايت تأثير مثبتى بر سلامت روان نداشته است [N IV-1 I]. از طرفى ديخر Rimaz و همكاران [19] و و و همكارش [r] نيز به ترتيب به اين نتيجه دست يافتند كه بين حمايت اجتماعى با نمره كلى كيفيت زندگى و رضايت از زندگى سالمندان رابطهاى وجود ندارد. ديخر متغيرى كه مى تواند سطح شادكامى را افزايش دهد و از افراد در مواجه با تأثيرات زيان آور دوران سالمندى محافظت كند قدردانى (Gratitude) است [rr-1 [r]. قدردانى بهعنوان يك احساس مثبت، يك سازوكار انطباقى محسوب شده كه افكار و اعمال را گسترش داده و توانايى شناختى را بهبود مىبخشد [سr]]. در اين راستا در بعضى يزوهشها بيانشده است كه قدردانى، بهزيستى ذهنى و شادكامى را افزايش مى دهد [YT]. براى مثال نتايج يزوهشهاى Al-Seheel و همكارش [Uه] و Lin [عr] حاكى از آن بودند كه قدردانى تأثير زيادى بر ميزان شادكامى و عاطفه مثبت دارد. در داخل
حفظ شادكامى (Happiness) يكى از مهمترين راهكارهاى مقابله با اضطرابى است كه در اثر شيوع بيمارى كوويد-19 در سالمندان افزايشيافته است [ [-1]]. شادكامى به احساس مكرر عاطفه مثبت و نداشتن احساسات منفى مانند افسردگى، اضطراب و يأس اشاره دارد [ب]. يزوهشهاى متعددى بيان كردند كه شادكامى در سالمندى افزايش مىيابد [F]. باينحال عوامل جسمى و روانى اجتماعى در سالمندى دستخوش تغيير شده [ه] و كاهش شادكامى سالمندان را به دنبال داشته است [V-V] فارغ از اين تناقضات يزوهشى كه خود لزوم بررسى بيشتر را مىطلبد، شادكامى بهعنوان يكى از عوامل مهم در سالمندى موفق به رسميت شناختهشده است

از طرفى روابط اجتماعى در دوره سالمندى اهميت بيشترى پيدا مى كند [F] و از ضروريات سالمندى موفق بهحساب مىآيد [9]. مهممترين عنصر اين روابط، حمايت اجتماعى ادراكشده (Perceived Social Support) مىباشد [ [ [ ] كه شامل درك سالمند از اين نكته است كه به جه ميزان مىتواند از دوستان، خانواده و افراد ديگر حمايت اجتماعى دريافت كند و در صورت نياز براى كمك گرفتن، اين افراد در دسترس او خواهند بود [11]. يثوهشهاى متعددى نشان مىدهند كه داشتن حمايت اجتماعى با عاطفه مثبت در سالمندى همراه است [Y I ]. براى مثال يافتههاى Tajvar و همكاران [سا] و Dumitrache و همكاران [1/] به ترتيب حاكى از آن بودند كه حمايت اجتماعى بهطور مستقيم با 


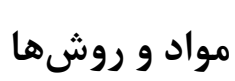

يزوهش حاضر از نوع توصيفى است. جامعه مورد بررسى زنان سالمند مناطق ب، \& و له شهر تهران بودند. علت انتخاب اين مناطق بهعنوان جامعه آمارى گيزوهش به دو دليل بود؛ دليل اول آنكه در تاريخ انجام يزوهش بر اساس آناليزهاى همه گيرى بخشهايى از منطقه سه، جهار و ينج شهر تهران از نقاط داغ كرونايى در تهران بهحساب مى آمدند و دوم به دليل نزديكى محل سكونت يزوهش در دسترس با توجه به شرايط يِيشآمده كرونايى در سطح شهر بود. درنهايت ازآنجايى كه تعداد اعضاى اين جامعه آمارى نامعلوم مىباشد، براى تعيين حجم نمونه آمارى نيز از فرمول محاسباتى كو كران كه در ادامه آمده است استفاده كرديد.

$$
n=\frac{Z_{1-\frac{\alpha}{2}}^{2} \times P \times(1-P)}{d^{2}}
$$

n حجم نمونه آمارى، d: درصد خطاى مجاز (در اينجا محاسبه با سطح خطاى هـ• • مىباشد)، Z: مقدار متغير نرمـال واحـد اسـتاندارد (در اينجا محاسبه با سطح اطمينان ه9 درصد مىباشد و مقدار آن برابر 9/9/ مىباشد)، p: مقدار نسبت صفت موجود در جامعه مىباشد، يعنى نشاندهنده نسبت افرادى است كه حمايت اجتماعى و قدردانى در آنها مىتواند شادكامى آنها را ييشبينى كند (مقدار p را مىتوان از طريق برآورد تقريبى از مطالعات قبلى و يا مطالعه مقدماتى به دست آورد كه اخر مقدار آن مشخص نباشد، مىتوان آن را ه • • p ر ا در نظر گرفت كه بالاترين حجم ممكن را مىدهد). در نهايت با توجه به فرمول كوكران تعداد نمونه آمارى براى

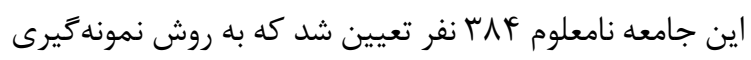

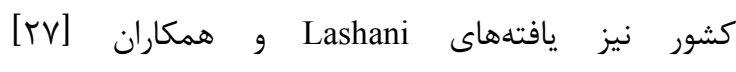
و [r^] DashtBozorgi] به ترتيب از تأثير گذارى قدردانى بر عاطفه مثبت و شادكامى و ارتباط آن با بهزيستى ذهنى سالمندان حكايت دارد. اين در حالى است كه در بعضى ديخر از يزوهشها بيانشده است كه قدردانى بهندرت و بهصورت غيرمستقيم، بهزيستى ذهنى (شادكامى) را افزايش مىدهد

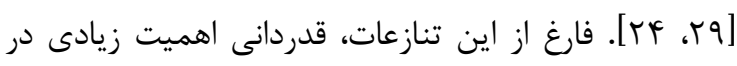

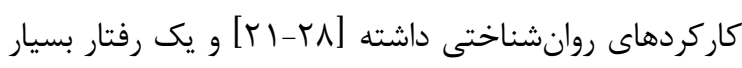
ارزشمند در فرهنگ، دين و زندگى مردم كشور ايران بهحساب مى آيد، اما اغلب مطالعات مربوط به اين زمينه در ايالات متحده انجام شده و تنها تعداد انخشت شمارى از يزوهشها با استفاده از نمونهاى آسيايى از جمله ايران انجام شده است، ازاينرو جهت تعميم نتايج و بررسى مناقشه موجود در اين حوزه انجام يزوهشهاى بيشترى در ديخر كشورها و فرهنَها ضرورى است [عr]. در اين راستا سلامت روان زنان سالمند از اولويتهاى هر جامعهاى است و آنها به علت متأثر شدن بيشتر از محيط خانوادگى و اجتماعى، بيشتر در معرض خطر هستند [.r]. با اين وجود بسيارى از حيطههاى مرتبط با سلامت زنان كمتر مورد توجه قرار گرفته است لذا بايد از طريق يروهشهاى علمى مورد شناسايى قرار زيرند تا آنگًاه بتوان بر اساس آنها راهبردهاى مناسب براى حفظ و ارتقاء سلامت زنان به كار كرفت [ـ[ب]. بنابراين يزوهش حاضر با هدف تعيين ارتباط قدردانى و حمايت اجتماعى ادراك شده با شادكامى زنان سالمند مناطق ب، أ و ه شهر تهران در سال 9 9ا در دوران همهَيرى بيمارى كوويد-9 ا انجامشده است. 


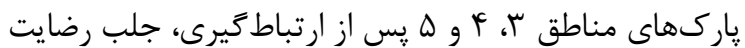
زنان سالمند، ابتداء هدف يزوهش براى آنها بيان كردند و با ارائه راهنمايى لازم برسشنامهها را در اختيار آنها قراردادند و از آنها خواسته شد كه بهدقت سؤالات را بخوانند و ياسخهاى موردنظر را متناسب با ويزگكىهاى خود انتخاب كنند و سؤالى را تا حد امكان بىجواب نكذارند. براى پاسخ گَيى به زنان سالمند شركت كننده در يزوهش، اين اطمينان داده شد كه اطلاعات دريافت شده از آنان بهصورت محرمانه خواهد ماند و كسانى كه مايل نيستند به اين سؤالات ياسخ دهند مى توانند در هر مرحلهاى از ياسخ گويى كه هستند همكارى خود را ادامه ندهند. همرجنين ويزّكىهاى جمعيت شناختى (دموكرافيك) شامل سن، سطح تحصيلات، وضعيت تأهل، محل سكونت و ابتلاء شخص يا نزديكان به كرونا از نمونهها ثبت و جمعآورى شد. ابزار مورداستفاده در اين يزوهش شامل جهار ابزار: 1معاينه مختصر وضعيت روانى، ؟- يرسشنامه قدردانى، بـمقياس קند بعدى حمايت اجتماعى ادراى شده و Fيرسشنامه شادكامى آكسفورد بودند كه در زير به توضيح

$$
\text { هركدام از اين ابزارها يرداختهشده است: }
$$

معاينه مختصر وضعيت روانى (Mini-Mental State Examination متداولترين ابزار غربالكرى اختلالات شناختى در سطح جهان است كه به زبانهاى مختلف ترجمه و در فرهنَّهاى مختلف استاندارد شده است. اين مقياس لا كَيه و جمعاً •ـ عبارت سؤالى دارد كه به دو بخش تقسيم مىشود. بخش اول ياسخدهى كلامى به برسشهاى جهتيابى، حافظه و توجه را در برمى كيرد. بخش دوم نيازمند خواندن و نوشتن است و
غير تصادفى در دسترس از پارك هاى مناطق لَ، † و ه تهران در بازه زمانى شهريور تا بهمن سال 99¥ا با توجه به محدوديتهاى بيمارى كرونا جمع آورى شدند. لازم به ذكر است پاركهاى منطقه بَ تهران عبارتاند از

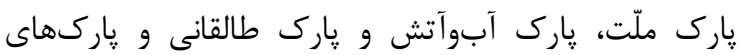
منطقه أ تهران نيز شامل ياركهاى ساحل، سبه شهر، شادى، فلاح، جنكلى شبان، ياس، لويزان و وليس و در نهايت يارك هاى منطقه ه تهر ان شامل ارم، بوستان جوانمردان، بارى جنكلى كوهسار، پارك تفريحى دره كن و پارك نهجالبلاغه مىباشند كه نمونه كَيرى از تمامى پاركهاى فوق انجام شده

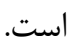
ملاكهاى ورود براى اين يزوهش عبارت بود از: ا- نمره بالاى FF در آزمون وضعيت روانى، Y- افراد •9 سال و بالاتر و r- تحصيلات راهنمايى يا بالاتر باشد و ملاكهاى خروج وجود اختلالات شناختى بر اساس معاينه مختصر وضعيت روانى و اختلالات روان يزشكى بر اساس خودكزارشدهى فرد بود. همرجنين بلمنظور جلوَيرى از خطاهاى بينايى در هنكام خواندن يرسشنامه براى زنان سالمند خوانا و درشت تهيه شد و بهمنظور رعايت كدهاى اخلاقى رضايتنامه كتبى آكاهانه از تمام زنان سالمند شركت كننده در تحقيق اخذ شد. براى اجراى يزوهش، يزوهش پارك ها، ساعات و روزهايى كه زنان سالمند بيشترى در محل ياركها حضور داشتند با توجه به اين كه به دليل كرونا حضور زنان سالمند در پاركها بسيار كاهش يافته بود، سرانجام با رعايت يروتكلهاى بهداشتى در هF نوبت با مراجعه به 
ه بر بررسى ارتباط قدردانى و حمايت اجتماعى ادراك شده با شاد كامى زنان سالمند ...

(سؤالات r و ع) از شش سؤال داراى نمرهزذارى معكوس هستند. اين : يرسشنامه نمره برش ندارد. هر فرد مىتواند نمرهاى بين حداقل 4 تا حداكثر r F را كسب كند كه نمره بالاتر به معنى داشتن قدردانى بيشتر است. در مطالعهاى كه سازندكان يرسشنامه انجام دادند، ضريب آلفاى كرونباخ مقياس Ar| • به دست آمد. همرجنين روايى همگراى مقياس مطلوب ارزيابى شد [سr]. در ايران نيز Lashani و همكاران

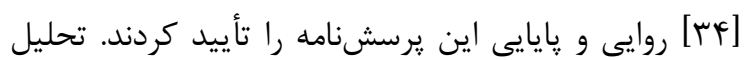
عاملى نيز تأييد كننده يك عامل اصلى براى اين زرسشنامه بود. همرجنين Ghamarani و همكاران [هـ] نيز روايى و پايايى اين يرسشنامه را تأييد كردند. همرجنين در مطالعه حاضر ضريب آلفاى كرونباخ براى اين يرسشنامه برابر با و9/• به

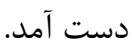
مقياس جندبعدى حمايت اجتماعى ادراكشده :(Multidimensional Scale of Perceived Social Support) مقياس جندبعدى حمايت اجتماعى ادراكشده يك ابزار مادهاى است و حمايت اجتماعى را از سه منبع خانواده، اجتماع و دوستان در اندازههاى هفتدرجهاى از 1 (كاملاً مخالفم) تا (كاملاً موافقم) مىسنجد. حداقل و حداكثر نمره فرد در كل V مقياس به ترتيب r| و و و در هر يك از زير مقياسهاى حمايت خانوادگى، اجتماعى و دوستان به ترتيب أ و ر Y محاسبه مىشود. نمره بالاتر نشاندهنده حمايت اجتماعى ادراكشده بيشتر است [عץ].Bruwer و همكاران ק پايايى درونى اين ابزار را آن تأييد كردند [rV]. در ايران نيز Salimi] و همكاران [^ץ] پايايى و روايى اين ابزار را تأييد كردند. نمره
شامل توانايى براى نامگذارى، انجام دستورات گفتارى يا نوشتارى، نوشتن يك جمله و كيى كردن يك شكل است. همه يرسشها به ترتيب يرسيده مىشود و نمره كل از جمع نمرات تكاليفى كه با موفقيت انجامشده (موفقيت = ا و عدم موفقيت = •)، حاصل مىشود. اين آزمون كاركردهاى مختلف شناختى را سنجيده و برآوردى كلى از وضعيت شناختى آزمودنى را فراهم مى كند. اين گرسشنامه در معاينات روانى جهت اختلالات شناختى مورد استفاده قرار مى گيرد و ينج محدوده از عملكرد شناختى را آزمايش مى كند (جهتيابى، ثبت، توجه و محاسبه، يادآورى و طراحى). حداكثر نمره آن ·队 بوده و نمرات سץ يا پايينتر نشاندهنده اختلال شناختى است (اختلال شناختى شديد = •-V_، اختلال شناختى خفيف يا متوسط= 1 | Folstein همكاران پايايى و روايى اين ابزار را در فرهنت اصلى تأييد كردند [اس]]. همرجنين هنجاريابى معاينه مختصر وضعيت شناختى سالمندان در شهر تهران از روايى و يايايى رضايتبخش، برخوردار بود و مورد تأييد قرار گرفت [rr]. همجنين در مطالعه حاضر ضريب آلفاى كرونباخ براى اين يرسشنامه برابر با سع| • به دست آمد. Gratitude Questionnaire-Six ) يرسشنامه قدردانى Item : يرسشنامه قدردانى يا سياسگزارى يك مقياس مختصر و خودگزارشى براى سنجش تمايل به تجربه قدردانى است. آزمودنىهاى اين يرسشنامه بايد به ع سؤال اين

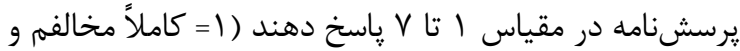
كاملاً موافقم). براى جلو گيرى از تعصب در ياسخ، دو سؤال =V 
ايران ترجمه و هنجاريابى شده و با اجراى فرم نهايى آزمون، يايايى و روايى آن را تأييد كردند. در مطالعه حاضر ضريب تربي آلفاى كرونباخ براى اين يرسشنامه برابر با بـ/ • به دست آمد. دادهاى يزوهش با استفاده از نسخه r ب نرمافزار SPSS و با روشهاى آمار توصيفى (فراوانى، درصد، ميانگين و انحراف معيار ) و ضريب همبستكى Pearson و تحليل ركرسيون خطى رئ קندكانه به روش كامبه گام (Stepwise) تجزيهوتحليل شدند. سطح معنىدارى آمارى در آزمونها هـ/• در نظر كرفته شد.

\section{نتايج}

تعداد شركتكنندكان در يزوهش حاضر ז1 از زنان سالمند بودند كه ميانكين و انحراف معيار استاندارد سنى آنها

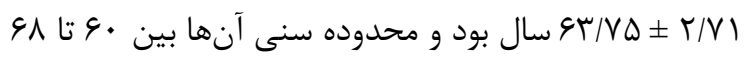
سال قرار داشت. جدول ا، ويزَّى هاى جمعيت شناختى نمونه مورد مطالعه را نشان مى دهد. جدول r، ويزگى هاى توصيفى متغيرهاى مورد مطالعه را نشان مىدهد. مطابق اين جدول ميانگين و انحراف استاندارد

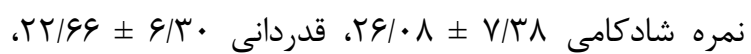

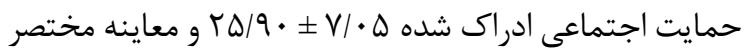

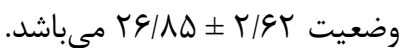

هر زير مقياس برحسب مجموع ارزش گزينههاى هر ماده (كاملاً مخالفم = 1، مخالفم = ז، تقر يباً مخالفم = "ا، نه مخالفم | نه موافقم = F، تقريباً موافقم = ل موافقم = צ، كاملاً موافقم IT) محاسبه مىشود. از جمع نمره تعداد كل مادهها (V = ماده) نيز نمره كل حمايت اجتماعى ادراك شده به دست مى آيد. ابعاد اين يرسشنامه و نيز سؤالات مربوط به هر بعد بلصورت زير است: حمايت اجتماعى دريافت شده از سوى خانواده: سؤالات ז، أ، 1، 11 حمايت اجتماعى دريافت شده از سوى دوستان سؤالات 9، V، 9 و ر rا حمايت اجتماعى دريافت شده از سوى ديكران سؤالات ا، ז، ه و • است [^ץ]]. همرجنين در مطالعه حاضر ضريب آلفاى كرونباخ براى كل يرسشنامه بر|A • به دست آمد.

Oxford Happiness ) يرسشنامه شادكامى آكسفورد Inventory

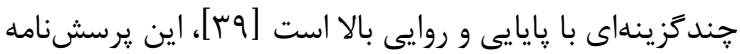
يك عاملى داراى qr سؤال F كزينهاى است كه جنان קه آزمودنى در ياسخ به هريك از تزينههاى الف، ب، ج، د را انتخاب كند به ترتيب • و ا و ك و ب نمره مى گيرد و در نتيجه نمره نهايى شادكامى در محدوده · تا AV نمره به دست مى آيد

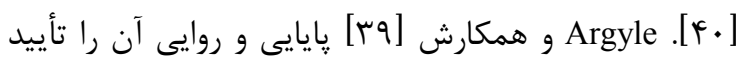
كردند. اين آزمون توسط Alipoor و همكارش [•• نيز در 
• ه بررسى ارتباط قدردانى و حمايت اجتماعى ادراكشده با شاد كامى زنان سالمند ...

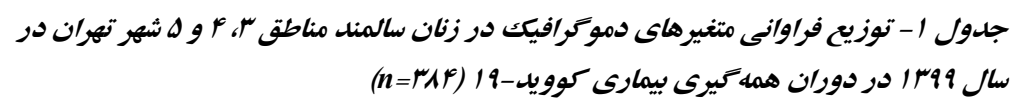

\begin{tabular}{|c|c|c|c|}
\hline درصد & فراوانى & سطح متغير & متغير \\
\hline $1 / 9$ & 4 & زير دييلم & \multirow{6}{*}{ سطح تحصيلات } \\
\hline $11 / \mathrm{V}$ & id & ديبلم & \\
\hline ir & is & كاردانى & \\
\hline$\varphi \& / 4$ & IVA & كارشناسى & \\
\hline $19 / 0$ & VD & كارشناسى ارشد & \\
\hline$\Lambda / 9$ & re & دكترى & \\
\hline $9 / 9$ & rی & 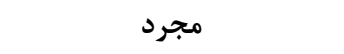 & \multirow{4}{*}{ وضعيت تأهل } \\
\hline$\Delta q / 1$ & TrV & متأهل & \\
\hline $11 / \mathrm{V}$ & id & مطلقه & \\
\hline $19 / \pi$ & VF & همسر فوت شده & \\
\hline$T V / Q$ & 1.9 & فرد مبتلا شده و بهبود يافته & \multirow{3}{*}{ وضعيت ابتلاء به كرونا } \\
\hline$r q / \mu$ & $|\Delta|$ & عدم ابتلاء فرد & \\
\hline 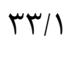 & ITV & ابتلاء يكى از نزديكان فرد & \\
\hline 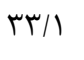 & ITV & منطقه سه شهر تهران & \multirow{3}{*}{ محل سكونت } \\
\hline$r V / T$ & Tr & منطقه جهار شهر تهران & \\
\hline$r q / V$ & 114 & منطقه ينج شهر تهران & \\
\hline
\end{tabular}

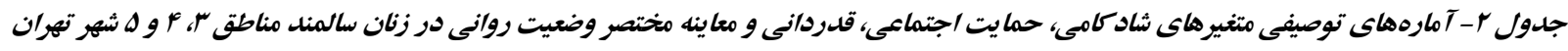

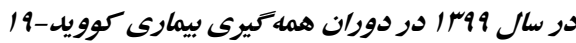

\begin{tabular}{|c|c|c|c|c|}
\hline بالاترين نمره & يايين ترين نمره & انحراف استاندارد & ميانغين & 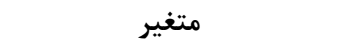 \\
\hline rᄉ & $\wedge$ & $\mathrm{V} / \mathrm{T \Lambda}$ & $r \varepsilon / \cdot \Lambda$ & شادكامى \\
\hline rᄉ & 9 & $V / \cdot \Delta$ & $r \Delta / q$. & حمايت اجتماعى \\
\hline ra & $\wedge$ & $\varepsilon / \Gamma$. & Tr/GG & قدردانى \\
\hline r. & rF & T/9T & $r \& / \wedge \Delta$ & معاينه مختصر وضعيت روانى \\
\hline
\end{tabular}

مقدار آزمون (Durbin-Watson=1/999) كه در محدوده آه تا ه/ ب قرار دارد، تأييد شد. مفروضه نرمال بودن توزيع دادهها نيز با استفاده از محاسبه جولخى (Skewness) و كشيدگى بررسى شد. در حالت كلى جنانجه جولگى و (Kurtosis) كشيدگى در بازه ץ- تا ץ+ قرار داشته باشند، دادهها از توزيع
در ادامه بهمنظور بررسى رابطه و جَكونكَى پِيشبينى شادكامى زنان سالمند بر اساس حمايت اجتماعى و قدردانى از آزمونهاى ضريب همبستخى گشتاورى Pearson و تحليل ركرسيون خطى جندگانه به شيوه گَامبه گام استفاده شده است. در اين راستا مفروضه مستقل بودن خطاها از يكديگر به 
جدول با، ضرايب همبستگى بين متغيرهاى يزوهش را نشان مىدهد. بررسى اين ضرايب نشان مىدهد كه شادكامى با حمايت اجتماعى و قدردانى رابطه مثبت و معنىدارى داشت، اما بين سن آزمودنىها و ميزان شادكامى رابطه معنىدارى يافت نشد. همجنين براى بررسى رابطه ساير متغيرهاى جمعيت شناختى، با شادكامى از آزمون تحليل واريانس يكطرفه استفاده شد كه نتايج اين آزمون حكايت از آن داشت كه بين هيجيك از متغيرهاى جمعيت شناختى

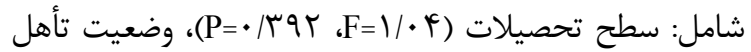

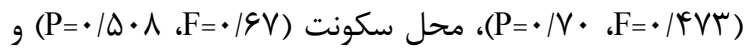
وضعيت ابتلاء به بيمارى كرونا (F=1/99، P=//AF)، با شادكامى رابطه معنى دار مشاهده نشد.
نرمال برخوردار مىباشند. مقدار جولگى مشاهده شده براى متغيرهاى شادكامى، حمايت اجتماعى و قدردانى به ترتيب

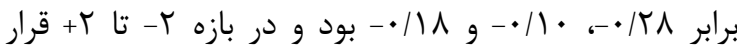
داشتند؛ يعنى از لحاظ كجى متغيرهاى مذكور نرمال بوده و توزيع آن متقارن بود. مقدار كشيدگى آنها نيز به ترتيب

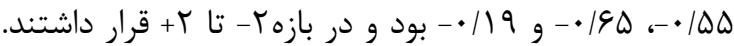
لذا اين مقادير، نشان مىدهند توزيع متغيرها از كشيدگى نرمال برخوردار بود. در نهايت به منظور تعيين همخطى קندكانه از آزمون تحمل (Tolerance) و عامل تورم واريانس (Variance inflation factor;VIF) در جدول r ارائه شده است. بنابراين يديده همخطى بين متغيرهاى مستقل وجود ندارد و در نتيجه با رعايت بيشفرضهاى آناليز تحليل ركرسيون، مىتوان از اين آزمون براى بررسى فرضيههاى يزوهش حاضر استفاده كرد.

جلدول - ماتريس همبستكى Pearson بين متغيرهاي كمّى مطالعه با شاد كامى در زنان سالمند

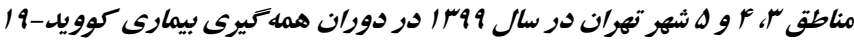

\begin{tabular}{|c|c|c|c|c|}
\hline سن (سال) & قدردانى & شادكامى & حمايت اجتماعى & متغير ها \\
\hline$\cdot 1 \cdot r$ & $* * / r r$ & $* * / \mathrm{A}$ & 1 & حمايت اجتماعى \\
\hline .1 .4 & $* * / f F$ & 1 & $* * / \vee \wedge$ & شاد كامى \\
\hline $.1+1$ & 1 & $* * /$ fF & $* * / r r$ & قدردانى \\
\hline
\end{tabular}

در مجموع ه 4 درصد از واريانس متغير شادكامى در زنان سالمند بلوسيله متغيرهاى پيشبين تبيين شده است. همجنين در جدول س، ضرايب استاندارد و غيراستاندارد رگرسيون ارائه شده است و همانطور كه مشاهده مىشود ضرايب بتاى متغيرهاى حمايت اجتماعى و قدردانى مثبت است. بنابراين، به نظر مىرسد با افزايش حمايت اجتماعى و
نتايج رگرسيون خطى جند گانه به روش گامبهَام در جدول أ نشان داد كه در كام اول حمايت اجتماعى وارد تحليلشده و اצ درصد از واريانس متغير شادكامى را تبيين كرده است

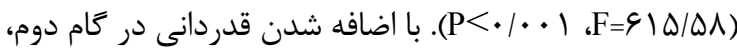
مقدار واريانس تبيين شده از ا\& درصد به ها درصد افزايش

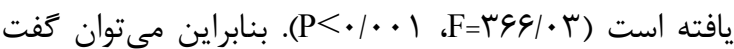


كو بر برسى ارتباط قدردانى و حمايت اجتماعى ادراكشده با شاد كامى زنان سالمند ...

قدردانى، ميزان شادكامى در زنان سالمند افزايش بيدا مى كند. در نتيجه اين يافتهها مىتوان كفت هر دو فرضيه يزوهش

تأييد مىشود.

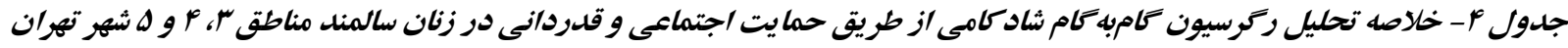

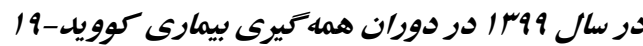

\begin{tabular}{|c|c|c|c|c|c|c|c|c|}
\hline \multicolumn{2}{|c|}{ مفروضه هم خطى } & \multirow{2}{*}{ Pقدار P P P } & \multirow{2}{*}{ مقدار t } & \multirow{2}{*}{ استاندارد شدار بتاى } & \multicolumn{2}{|c|}{ ضرايب غيراستاندارد } & \multirow{2}{*}{ متغير } & \multirow{2}{*}{ كام } \\
\hline تحمل & تورم واريانس & & & & خطاى استاندارد بتا & بتا & & \\
\hline 1 & 1 & $<+1 .+1$ & rF/AII & ./マ^s & 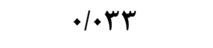 & - $|A r|$ & حمايت اجتماعى & 1 \\
\hline $1 / 1 r$ & .119 & $*<+/ * 1$ & $r Y / \Delta \Delta T$ & $. / \mathrm{V} / \mathrm{S}$ & I.r & - /VFq & حمايت اجتماعى & $r$ \\
\hline $1 / 1 r$ & .119 & $<\bullet / 1$ & $9 / 991$ & 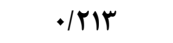 &.$/ \cdot r v$ &.$/ T F q$ & قدردانى & \\
\hline
\end{tabular}

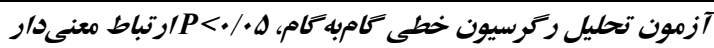

علاقه و تأييد و ارزش قراركرفته و متعلق به شبكهاى از

ارتباطات و وظايف متقابل است. بهعبارتىديخر، با دريافت

نتايج يزوهش حاضر حاكى از آن بود كه شادكامى با حمايت

حمايت اجتماعى، منابع روانشناختى محسوسى براى افراد فراهم مىشود تا بتوانند با شرايط استرسزاى زندكى و اجتماعى رابطه مثبت و معنى دارى دارد. اين يافته از يزوهش مشكلات روزانه كنار بيايند و در نتيجه شادكامى بيثترى را احساس كنند. از طرفى شادكامى را شامل سه جزء است كه عبارتاند از: ا- جزء شناختى كه مبين نوعى و يردازش است كه به خوشبينى فرد منجر مىشود، r- جزء عاطفى و هيجانى كه همان خلق مثبت و شاد است، بـ- جزء اجتماعى كه بيان كسترش روابط اجتماعى فرد با ديكران است [عا-9، ع]. ازاينرو حمايت اجتماعى حداقل مىتواند جزء اجتماعى شادكامى را با افزايش اعتمادبهنفس، خود ابرازى و عزتنفس تأمين كرده و باعث رضايت فرد از زندگى و شادكامى بيشترى

شود [0] يافته ديخر اين يزوهش بيانَر رابطه مثبت قدرانى و شادكامى است. اين يافته با نتايج يزوهشهاى Al-Seheel و

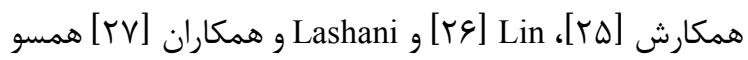
حاضر با نتايج يُوهشهاى Tajvar و همكاران [با]، Keykhosravi Beygzadeh و وممكاران [ D و همكاران [10] همسو و هماهنگ است و با نتايج يزوهشهاى Ang و همكارش [IV] و Rimaz و همكاران [19] كه بيان كردند بين حمايت اجتماعى و ييامدهاى مثبت آن ارتباطى وجود ندارد و يا پيامد منفى را براى حمايت اجتماعى متصور شدند، همخوانى ندارد. در تبيين اين يافته مىتوان كفت حمايت اجتماعى عنصرى كليدى براى ادامه زندگى بهويزه احساس رضايتمندى از زندگى است. جراكه از طريق حمايت اجتماعى افراد مىتوانند فشارهاى روانى خود را تحمل كنند و نيروى مقابله براى مواجهه موفقيتآميز در زمان دركيرى با شرايط تنشزا را به دست آورند. داشتن تماس اجتماعى مىتواند فرد را به اين باور برساند كه مورد عشق و 


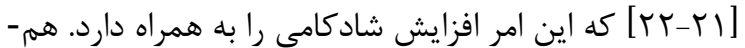
جنين قدردانى با توجه به تأثيرات سازگًاى لذتبخش مىتواند با بهزيستى هيجانى در ارتباط باشد. اين سازگارى لذتبخش، تمايل افراد را براى توجه به تجارب مثبت بيشتر مى كند. لذا شكركزار بودن تمرينى براى نكَرش مثبت داشتن به تجارب زندگى است كه اين امر باعث مىشود توانايى مقابله

با عوامل استرسزاى زندگى در فرد تقويت شود [بץ]]. علاوه بر اين سه مرحله در خَّونكى كمك كردن قدردانى در كاهش نشانههاى افسردىى و اضطراب را مطرح است: اول اينكه فعاليتهاى مثبت (شكرَزار بودن)، حالت مثبت را در فرد افزايش و حالت منفى را كاهش مىدهد، در مرحلهى دوم اين تغير حالت به سمت مثبت بودن، انعطاف، مثبت نكرى و ذهن آَاهى بيشترى در فرد ايجاد مى كند و درنهايت اين تغيير حالت مثبت ذهن، افراد را به سمت انجام فعاليتهاى مثبتى مثل ارتباط كرفتن با ديخران، دنبال كردن اهداف و علايق و تمرين كردن رفتارهاى سالم هدايت مى كند [FY]. افراد شكر كزارييامدهاى مثبت زندگى خود را مرور مى كنند و در اين حين به نيروهايى كه اين ييامدهاى مثبت را ايجاد كردند مثل يك فرد يا وجود و نيروى فوق بشرى (خداوند) آكاه مىشوند و به خاطر آنها قدردانى مى كنند [سب]. افراد شكركزار وقتى آكاه مىشوند نيروهاى ديخر، تغييرات مثبت زيادى در زندكى آنها ايجاد كرده است، لذت بيشترى از زندگى مىبرند و اين لذت بردن از زندكَ، آنها را به سمت

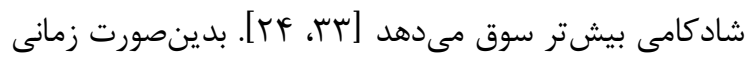
كه افراد به نعمتهاى دريافت شده از جانب خدا، افراد يا هر نيروى ديخرى تمركز مى كند و آنها را بهعنوان هديهاى در
بوده اما با نتايج يزوهشهايى كه بيان كردند قدردانى بلندرت و بلصورت غيرمستقيم، بهزيستى ذهنى (شادكامى) را افزايش مىدهد [ [r] همخوانى نداشت. در تبيين اين عدم همخوانى مىتوان كفت شادكامى تحت تأثير وراثت، شرايط زندگى، ويزگكىهاى شناختى و عاطفى فرد است. همرجنين بعد شناختى شادكامى، ارزيابى شخصى فرد از رضايت از زندگى و بعد عاطفى به عاطفه مثبت و عاطفه منفى مربوط مىشود

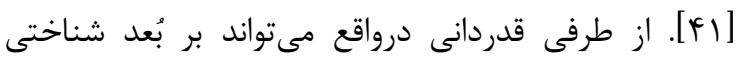
شادكامى تأثير بحذارد و از اين طريق موجب افزايش شادكامى كردد [F|[ [F] اما در دو حالت ممكن است تأثيرى بر شادكامى نداشته باشد، حالت اول مربوط به برخى از افراد است كه بلهورت ارثى ترايش كمترى به شادكامى نشان مىدهند و حالت دوم زمانى است كه شرايط مشكلآفرين زندگى موجب شكل گيرى عواطف منفى در افراد مى گردد. اين عواطف منفى از تجربه كردن عواطف مثبت جلوكيرى مى كند و بُعد شناختى شادكامى را تحت تأثير قرار داده و به اين صورت از تجربه ذهنى شادكامى مى كاهد. از طرفى ديخر ممكن است قدردانى از طريق ويزَّىهاى شخصيتى و ميانجىهاى روانى ديخرى بلصورت غيرمستقيم بر شادكامى تأثير بخذارد. همرجنين در تبيين ديخرى مىتوان كفت كه قدردانى بهعنوان كليد شادى در نظر ترفته شده است و افرادى كه سطح بالاترى از قدردانى را دارا هستند افسردىى و اضطراب كمترى را تجربه مى كنند. افراد شكرَزار به آنجه دارند راضى مىباشند و كمتر دجار احساساتى مانند ناميدى، خشم، تنفر و حسادت مىشوند [Fr]، از طرفى فرد شكرَزار با قدردان بودن از نكات مثبت زندگى، معنادارى بيشترى را در زندگى احساس مى كند 
از گرسشنامههاى فرم كوتاه براى تحقيقات سالمندان طراحى و استفاده شود. همرجنين جهت سنجش قدردانى، شادكامى و حمايت اجتماعى در تحقيقات بعدى از روشهايى استفاده شود كه صرفاً مبتنى بر خودكزارشدهى نباشد (از جمله مصاحبه و روشهاى غير خودگزارشدهى). از طرفى، انجام مطالعه بر روى يك نمونه از زنان سالمند در دسترس در سطح ياركهاى مناطق "ا، أ و ه شهر تهران اشاره كرد، بنابراين تعميم نتايج آن به ديگر سالمندان و ديگر مناطق شهر تهران با احتياط صورت گيرد. در اين راستا پيشنهاد مىشود اين مطالعه در مردان سالمند و در مناطق ديگر شهر تهران و ساير شهرهاى كشور نيز انجام شود تا به نتيجهَيرىهاى دقيقتر منجر كردد.

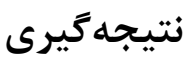

برحسب نتايج اين يزوهش امكان ييشبينى شادكامى زنان سالمند در دوران همهگيرى بيمارى كوويد-19 بر اساس قدردانى و حمايت اجتماعى ادراكشده وجود دارد. بنابراين توصيه مىشود در تدوين برنامههاى حمايتى و درمانى جهت حفظ شادكامى زنان سالمند در ايام قرنطينه به اين متغيرها نيز توجه شود. تشكر و قدردانى

در پايان نويسندكان از زنان سالمندى كه در پاركهاى مناطق r، أ و ه شهر تهران حضور داشتند و با صبر و صداقت خود لازمه به ثمر رسيدن اين يروهش شدند تشكر و قدردانى را به عمل

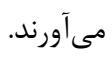

زندگى خود مىبينند، احساس شادكامى بالايى را تجربه مى كنند [Fه يك نكته دراين بين حائز اهميت است كه يزوهشها نشان دادهاند كه افراد تمايل زيادى به افكار منفى دارند و وقايع منفى قسمتى از زندگى است كه وقوع بعضى از آنها در كنترل فرد نيست اما با فرآيندهاى تفكر مثبت داشتن و قدردانى

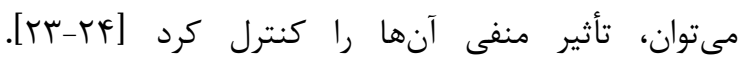
بدينصورت كه افراد منعطف يس از وقوع اتفاقات منفى زندگى و در مواجه با شرايط اضطرابآور، با توجه كردن به احساسات مثبتى مثل قدردانى سريعتر به حالت عادى برمى گردند. پس قدردانى عامل مهمى در افزايش تابآورى افراد در مواجه با اتفاقات منفى زندگى (مثل مشكلات دوره سالمندى) است [Fها]. باططورى كه قدردانى و تمركز بيشتر به نقاط قوت، اميد بيشترى در افراد ايجاد مى كند كه اين امر فرد را قادر مىسازد كه دررسيدن به اهداف خود كوشش بيشترى كند و درنتيجه شادكامى بيشترى را تجربه خواهند كرد [Yr]. در انتها با توجه به نتايج بلدستآمده توصيه مىشود از نتايج اين يزوهش در مراكز درمانى و مشاورهاى سالمندان مداخلاتى در جهت افزايش شادكامى زنان سالمند با توجه به نقش قدردانى و حمايت اجتماعى در دوران همهگيرى كرونا ويروس طراحى و استفاده گردد. از محدوديتهاى يزوهش حاضر مىتوان به تعداد زياد يرسشنامهها براى زنان سالمند، روش خودگزارشدهى سنجش متغيرهاى اشاره كرد و بر اين اساس پيشنههاد مى گردد 


\section{References}

[1] Saberi A, Goodarzi S, Asgari Gandmani R. The effect of social capital on coronavirus anxiety among three groups of the elderly based on physical activity before and after social distance. SJSCM 2020; 8(1): 99-121. [Farsi]

[2] Fathi A, Sadegi S, Malekirad A, Rostami H, Abdolmohamadi K. The Effect of Promoting Health Lifestyle Dimensions and Psychological Well-Being in Corona (Covid 19) Anxiety in Tabriz Azad University Students. JAUMS 2020; 23(5): In Press. [Farsi]

[3] Belen H, Yildirim M. Psychometric analysis of inflexibility of happiness in undergraduate students: A reliability and validity study. JPSP 2020; 4(1): 69-78.

[4] Galambos NL, Krahn HJ, Johnson MD, Lachman ME.The U shape of happiness across the life course: Expanding the discussion. PPS 2020; 15(4): 898-912.

[5] Godoy-Izquierdo D, Moreno RL, Pérez MLV, Serrano FA, García JFG. Correlates of happiness among older Spanish institutionalised and non- institutionalised adults. JHS 2013; 14(2): 389-

414.

[6] Greenberg AE, Mogilner C. Consumer debt and satisfaction in life. JEP: Applied 2021; 27(1): 112.

[7] Baird BM, Lucas RE, Donnellan MB. Life satisfaction across the lifespan: Findings from two nationally representative panel studies. SINR 2010; 99(2): 183-203.

[8] Waldinger RJ, Schulz MS. What's love got to do with it? Social functioning, perceived health, and daily happiness in married octogenarians. JPA 2010; 25(2): 422-31.

[9] Olaya B, Domènech-Abella J, Moneta MV, Lara E, Caballero FF, Rico-Uribe LA, et al. All-cause mortality and multimorbidity in older adults: The role of social support and loneliness. JEG 2017; 99: 120-6.

[10] Nasiri Z, Dadkhah A, Khodabakhshi Koulai A. Investigate and Comparsion Self-Esteem and Happiness among Residential and Non- 
ه૬ بورسى ارتباط قدردانى و حمايت اجتماعى ادراكشده با شاد كامى زنان سالمند ...

Residential Old People. IJA 2012; 7(2): 18-25. [Farsi]

[11] Liu D, Xi J, Hall B J, Fu M, Zhang B, Guo J, et al. Attitudes toward aging, social support and depression among older adults: Difference by urban and rural areas in China. JAD 2020: 274:85-92.

[12] Windsor TD, Anstey KJ. Age differences in psychosocial predictors of positive and negative affect: A longitudinal investigation of young, midlife, and older adults. JPA 2010; 25(3): 64152.

[13] Tajvar M, Fletcher A, Grundy E. Exploring associations between social support and mental health in older people: a systematic narrative review. IJADC 2016; 1(2): 174-93.

[14] Dumitrache CG, Rubio L, Rubio-Herrera R. Perceived health status and life satisfaction in old age, and the moderating role of social support. $A M H 2017 ; 21(7): 751-7$.

[15] Keykhosravi Beygzadeh Z, Rezaei A, Khalouei Y. The Relationship between Social Support and Life Satisfaction with Happiness among Home-
Dwelling Older Adults in Shiraz. IJA 2015; 10(2): 172-9. [Farsi]

[16] Goudarz M, Foroughan M, Makarem A, Rashedi V. Relationship between social support and subjective well-being in older adults. IJA 2015; 10(3): 110-9. [Farsi]

[17] Ang S, Malhotra R. Association of received social support with depressive symptoms among older males and females in Singapore: Is personal mastery an inconsistent mediator.SSM 2016; 153: 165-73

[18] Croezen S, Picavet HSJ, Haveman-Nies A, Verschuren WM, de Groot LC, van't Veer P. Do positive or negative experiences of social support relate to current and future health? Results from the Doetinchem Cohort Study. ВMCРH 2012; 12(1): 1-8.

[19] Rimaz S, gharibnavaz H, Abolghasemi J, Seraji S. The Relationship of Different Dimensions of Social Support with Older Adults' Quality Of Life in the 8th District of Tehran in 2013. JECH 2015; 2(1): 29-37. [Farsi]

[20] Momeni K, Rafiee Z. Correlation of Social 
Support and Religious Orientation with Life Satisfaction in the Elderly. IJA 2018; 13(1): 5061. [Farsi]

[21] Dickens LR. Using gratitude to promote positive change: A series of meta-analyses investigating the effectiveness of gratitude interventions. BASP 2017; 39(4): 193-208.

[22] Varaee P, Poordad S, Afshari S, Mirshamsi Z. The prediction of suicidal thoughts in the elderly on the basis of gratitude and self-compassion. $J G$ 2019; 4(1): 9-11. [Farsi]

[23] Fredrickson BL. The broaden-and-build theory of positive emotions. Philosophical Transactions of the Royal Society of London. SBBS 2004; 359(1449): 1367-77.

[24] Portocarrero FF, Gonzalez K, Ekema-Agbaw M.A meta-analytic review of the relationship between dispositional gratitude and well-being. PID 2020; 164: 101-10.

[25] Al-Seheel AY, Noor NM. Effects of an Islamicbased gratitude strategy on Muslim students' level of happiness. MHRC 2016; 19(7): 686703
[26] Lin C-C. The roles of social support and coping style in the relationship between gratitude and well-being. PID 2016; 89: 13-8.

[27] Lashani Z, Shaeiri MR, Asghari-Moghadam MA, Golzari M. Effect of Gratitude Strategies on Positive Affectivity, Happiness and Optimism. IJPCP 2012; 18(2): 157-66. [Farsi]

[28] Dasht Bozorgi z. The role of amnesty, gratitude and humility in predicting the mental well-being of the elderly. PPR 2017; 3(2): 67-78. [Farsi]

[29] Jans-Beken L, Jacobs N, Janssens M, Peeters S, Reijnders J, Lechner L, et al. Gratitude and health: An updated review. TJPP 2020; 15(6): 743-82.

[30] Rezaee N, Salsali M, Jahantigh M. Identification of women's health dimensions: a review on qualitative studies. IJNR 2015; 10 (3): 118-30. [Farsi]

[31] Folstein MF, Folstein SE, McHugh PR. "Minimental state": a practical method for grading the cognitive state of patients for the clinician. $J P R$ 1975; 12(3): 189-98. 
[32] Foroughan M, Jafari Z, Shirin Bayan P, Ghaem Magham Farahani Z, Rahgozar M. Validation of Mini- Mental State Examination (MMSE) in The Elderly Population of Tehran.ACS 2008; 10(2): 29-37. [Farsi]

[33] McCullough ME, Emmons RA, Tsang J-A. The grateful disposition: a conceptual and empirical topography. JPSP 2002; 82(1): 112-27.

[34] Lashani Z, Shairi M, Panahi Talkhtestani S. Validity and reliability of the Persian version of the Gratitude Scale (GQ-6) in non-clinical samples. JCP 2014; 3(12): 38-52. [Farsi]

[35] Ghamarani A, Kajbaf M B, Oreyzi H R, Amiri S. The study of the validity and reliability of the Gratitude Questionnaire -6 (GQ-6) in high school students. RPH 2009; 3(1): 77-86. [Farsi]

[36] Zimet GD, Dahlem NW, Zimet SG, Farley GK. The multidimensional scale of perceived social support. JPA 1988; 52(1): 30-41.

[37] Bruwer B, Emsley R, Kidd M, Lochner C, Seedat S. Psychometric properties of the Multidimensional Scale of Perceived Social Support in youth. JCP 2008; 49(2): 195-201.
[38] Salimi A, Jokar B, Nikpour R. Internet communication in life: The role of perceived social support and loneliness in the use of the Internet. JPS 2009; 5(3): 81-102. [Farsi]

[39] Argyle M, Lu L. The happiness of extraverts. PID 1990; 11(10): 1011-7.

[40] Alipoor a, Noorbala AA. A Preliminary Evaluation of the Validity and Reliability of the Oxford Happiness Questionnaire in Students in the Universities of Tehran. IJPCP 1999; 5(1): 55-66. [Farsi]

[41] Pavot W, Diener E. Happiness experienced: The science of subjective well-being. In S. A. David, I. Boniwell, \& A. Conley Ayers (Eds.), the oxford handbook of happiness.UK: OU Press $2013 ; 134-51$.

[42] Manala MJ. Gratitude as a Christian lifestyle: An Afro-reformed theological perspective. HTSTS 2018: 74(4): 1-8.

[43] Lyubomirsky S, Sheldon KM, Schkade D. Pursuing happiness: the architecture of sustainable change. $R G P$ 2005; 9(2): 111-31. 
[44] Layous K, Chancellor J, Lyubomirsky S, Wang L, Doraiswamy PM. Delivering happiness: Translating positive psychology intervention research for treating major and minor depressive disorders. JACM 2011; 17(8): 675-83.
[45] Wood AM, Froh JJ, Geraghty AW. (2010). Gratitude and well-being: A review and theoretical integration. CPR 2010; 30(7): 890905. 
DV بررسى ارتباط قدردانى و حمايت اجتماعى ادراكشده با شاد كامى زنان سالمند ...

\title{
Investigating the Relationship between Gratitude and Perceived Social Support and Happiness of Elderly Women in Districts 3, 4, and 5 of Tehran in 2020 during the Epidemic of Covid-19 Disease: A Descriptive Study
}

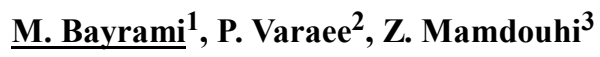 \\ Received: 28/03/21 Sent for Revision: 14/04/21 Received Revised Manuscript: 30/05/21 Accepted: 31/05/21
}

Background and Objectives: Happiness is a positive psychological variable that can affect the lives of the elderly. Therefore, the present study was conducted to determine the relationship between happiness and social support and appreciation in older women.

Materials and Methods: The present study is descriptive. For this study, 384 elderly women in districts 3, 4, and 5 of Tehran in 2020 were selected as the sample by the available sampling method. Gratitude Questionnaire-Six-Item Form, Multidimensional Scale of Perceived Social Support, and Oxford Happiness Inventory were used to collect data. Finally, after 54 times referring to the parks in the $3^{\text {rd }}, 4^{\text {th }}$, and $5^{\text {th }}$ districts of Tehran, the researchers were able to collect the data of the present study and the participants answered the research questionnaires. Pearson's correlation coefficient and stepwise linear regression analysis were used to analyze the data.

Results: Mean and standard deviation of the variable of happiness were 26.08 \pm 7.38 , social support 25.90 \pm 7.05 , gratitude 22.66 \pm 6.30 , brief examination of mental status $26.85 \pm 2.62$, and age $63.75 \pm 2.71$. The results of Pearson's correlation test showed that there was a positive and significant relationship between happiness and support Social $(\mathrm{r}=0.78, \mathrm{p}<0.001)$ and gratitude $(\mathrm{r}=0.44, \mathrm{p}<0.001)$. The results of stepwise regression analysis also showed that social support $(\beta=0.716, p<0.001)$ and after that gratitude $(\beta=0.213, \mathrm{p}<0.001)$ were able to predict $65 \%$ of happiness changes. Conclusion: Gratitude and social support are directly related to happiness and can positively predict happiness. Therefore, it appears that paying attention to the concept of gratitude and social support in the treatment and counseling programs as an effective method to increase the happiness of older women will be useful.

Key words: Social support, Elderly women, Happiness, Gratitude, Coronavirus, Tehran

Funding: This study did not have any funds.

Conflict of interest: None declared.

Ethical approval: Following the ethics of research in this article, all rights related to research ethics are respected.

How to cite this article: Bayrami M, Varaee P, Mamdouhi Z. Investigating the Relationship Between Gratitude and Perceived Social Support and Happiness of Elderly Women in Districts 3, 4, and 5 of Tehran in 2020 During the Epidemic of Covid-19 Disease: A Descriptive Study. J Rafsanjan Univ Med Sci 2021; 20 (5): 554-70. [Farsi]

1 - Prof., Dept. of Psychology, Faculty of Psychology and Educational Sciences, University of Tabriz, Tabriz, Iran, ORCID: 0000-0002-5015-2585 (Corresponding Author) Tel: (041) 3341133, Fax: (041) 3341133, E-mail: Dr.bayrami@yahoo.com

2-PhD Student in Clinical Psychology, Dept. of Psychology, Faculty of Psychology and Educational Sciences, University of Tabriz, Tabriz, Iran, ORCID: 0000-0002-7538-661X

3-MSc Student in General Psychology, Dept. of Psychology, Faculty of Humanities and Social Sciences, Ardakan University, Ardakan, Iran, ORCID: 0000-0001-8415-9390

دوره ·r. IF شماره ه، سال IF مجله دانشگاه علوم پزشكى رفسنجان 